Article

\title{
Chromate Reductase YieF from Escherichia coli Enhances Hexavalent Chromium Resistance of Human HepG2 Cells
}

\author{
Xuan Liu ${ }^{1, \dagger}$, Gaofeng Wu ${ }^{1, \dagger}$, Yanli Zhang ${ }^{1}$, Dan Wu ${ }^{1}$, Xiangkai Li ${ }^{2}$ and Pu Liu ${ }^{1, *}$ \\ 1 Department of Developmental Biology, School of Life Sciences, Lanzhou University, \\ Lanzhou 730000, China; E-Mails: kathyliu0505@gmail.com (X.L.); wugf12@1zu.edu.cn (G.W.); \\ zhangyanli12@1zu.edu.cn (Y.Z.); wudan11@1zu.edu.cn (D.W.) \\ 2 Key Laboratory of Cell Activities and Stress Adaptations, School of Life Sciences, \\ Lanzhou University, Lanzhou 730000, China; E-Mail: xkli@1zu.edu.cn \\ $\dagger$ These authors contributed equally to this work. \\ * Author to whom correspondence should be addressed; E-Mail: liupu@lzu.edu.cn; \\ Tel.: +86-931-891-2561; Fax: +86-931-891-2560.
}

Academic Editor: Ji-Dong Gu

Received: 9 February 2015 / Accepted: 13 May 2015 / Published: 26 May 2015

\begin{abstract}
Hexavalent chromium (Cr(VI)) is a serious environmental pollutant and human toxicant. Mammalian cells are very sensitive to chromate as they lack efficient chromate detoxifying strategy, e.g., chromate-reducing genes that are widely present in prokaryotes. To test whether introduction of prokaryotic chromate-reducing gene into mammalian cells could render higher chromate resistance, an Escherichia coli chromate-reducing gene yieF was transfected into human HepG2 cells. The expression of yieF was measured in stably transfected cells HepG2-YieF by quantitative RT-PCR and found up-regulated by 3.89-fold upon $\mathrm{Cr}(\mathrm{VI})$ induction. In chromate-reducing ability test, HepG2-YieF cells that harbored the reductase showed significantly higher reducing ability of $\mathrm{Cr}(\mathrm{VI})$ than HepG2 control cells. This result was further supported by the evidence of increased $\mathrm{Cr}(\mathrm{VI})$-removing ability of crude cell extract of HepG2-YieF. Moreover, HepG2-YieF demonstrated 10\% higher viability and decreased expression of GSH synthesizing enzymes under $\mathrm{Cr}(\mathrm{VI})$ stress. Subcellular localization of YieF was determined by tracing GFP-YieF fusion protein that was detected in both nucleus and cytoplasm by laser confocal microscopy. Altogether, this study successfully demonstrated that the expression of a prokaryotic $\mathrm{Cr}(\mathrm{VI})$-reducing gene yieF endowed mammalian cell HepG2 with enhanced chromate resistance, which brought new insight of $\mathrm{Cr}(\mathrm{VI})$ detoxification in mammalian cells.
\end{abstract}


Keywords: chromate reduction; yieF; HepG2; transfection; $\mathrm{Cr}(\mathrm{VI})$ resistance

\section{Introduction}

Chromium ( $\mathrm{Cr}$ ) is a heavy metal that is widely used in paints and pigments, leather, metal plating, wood preservation, etc. [1,2]. Chromium-contaminated wastes generated from industrial processes and released into the environment have resulted in the contamination of arable land and water. In the environment, $\mathrm{Cr}$ ions exist in two common oxidation states. The principal one is $\mathrm{Cr}$ (III), the biological role of which became controversial in recent years, although it used to be accepted as an essential element [3]. The other one is $\mathrm{Cr}(\mathrm{VI})$, a carcinogen that is highly soluble and easily transported in water [4]. Numerous studies illustrated the toxicity, mutagenicity, and carcinogenicity risk associated with chromate exposure [5,6]. Hence $\mathrm{Cr}(\mathrm{VI})$ is more toxic than $\mathrm{Cr}(\mathrm{III})$ [7]. Both the International Agency for Research on Cancer and the US Environmental Protection Agency list classified Cr(VI)-containing compounds as Group 1 human carcinogens [8]. Cr(VI) contamination is a serious environmental problem universal, and there are billions of people at threat in the world as they drink water containing carcinogenic quantities of $\mathrm{Cr}(\mathrm{VI})[9,10]$.

Due to its structural similarity to $\mathrm{SO}_{4}{ }^{2-}$, chromate oxyanion can cross the plasma membranes of both bacterial and eukaryotic cells through non-specific phosphate/sulfate anionic transporters [11]. A high concentration of intracellular $\mathrm{Cr}(\mathrm{VI})$ can cause oxidative stress, DNA damage, and modulate the activity of regulatory apoptotic gene $p 53[12,13]$.

The reduction of $\mathrm{Cr}(\mathrm{VI})$ in mammalian cells mainly relies on metabolites such as ascorbic acid and low molecular weight thiols including reduced glutathione (GSH) and cysteine [14]. Mammalian cells have also been found to be extremely sensitive to chromium. The $50 \%$ lethal dose of $\mathrm{Cr}(\mathrm{VI})$ in mammalian cells is as low as $0.15 \mu \mathrm{g} / \mathrm{mL}$ [15], much lower than the hygienic standard for drinking water of China which was $0.05 \mathrm{mg} / \mathrm{L}$ for $\mathrm{Cr}$ (VI) (GB5749-2006). On the other hand, many microorganisms are highly resistant to $\mathrm{Cr}(\mathrm{VI})$, employing different mechanisms including efflux or precipitation of $\mathrm{Cr}$ and reduction of $\mathrm{Cr}$ (VI) by chromate reductases. Bacteria, such as Escherichia coli, Pseudomonas putita and Bacillus subtilis, can reduce $\mathrm{Cr}(\mathrm{VI})$ to $\mathrm{Cr}(\mathrm{III})$ and significantly detoxify $\mathrm{Cr}(\mathrm{VI})$ [16-18]. Correspondent chromate reductases, such as YieF and NfsA in Escherichia coli [19,20], ChrR in Pseudomonas putita [21] and NfrA in Bacillus subtilis [22], have been reported in related studies, whereas no effective reductase has been discovered in mammalian cells.

In this study, to test whether prokaryotic chromate reductase could enhance chromate tolerance of mammalian cells, we cloned gene yieF, which conferred chromium resistance in Escherichia coli to human hepatocellular carcinoma cell line HepG2. The chromate-resistance capabilities of the stable transfectants were subsequently analyzed. The findings might bring some new insight of heavy metal detoxification in mammalian cells.

\section{Results and Discussions}

The hexavalent chromium compounds can cause various biological damages and strong oxidizing effects in eukaryotes including humans [23,24]. In tobacco plants, Jin et al. [25] have successfully 
transformed the chromate-reducing gene $c h r R$ into tobacco plants and found $c h r R$ enhanced the $\operatorname{Cr}(\mathrm{VI})$ reduction ability of tobacco leaf disks. It is therefore intriguing to know whether the expression of the $\mathrm{Cr}(\mathrm{VI})$-reducing gene in mammalian cells could similarly reduce the toxic compounds of $\mathrm{Cr}(\mathrm{VI})$ and enhance the tolerence to $\mathrm{Cr}(\mathrm{VI})$.

\subsection{Expression of YieF under Cr(VI) Stress}

Stable HepG2-YieF cells and controls were cultured with or without $5 \mu \mathrm{M} \mathrm{Cr}(\mathrm{VI})$ to determine the relative expression level of yieF. The expression of yieF was found upregulated by 3.5 -fold with $\mathrm{Cr}(\mathrm{VI})$ treatment while no induction was observed in control cells (Figure 1A). This result indicated that gene $y i e F$ was expressed in HepG2 and the expression could be induced by the addition of chromate although the expression vector carrying yieF was non-inducible. The presence of YieF protein was confirmed by flow cytometry and western blotting using antibodies against Enhanced Green Fluorescent Protein (EGFP) in EGFP-YieF-HepG2 cells transiently expressing EGFP-YieF fusion protein (Figure 1B). The fluorescence intensity was $22.5 \%$, reflecting relatively low efficiency of transfection (Figure S1).

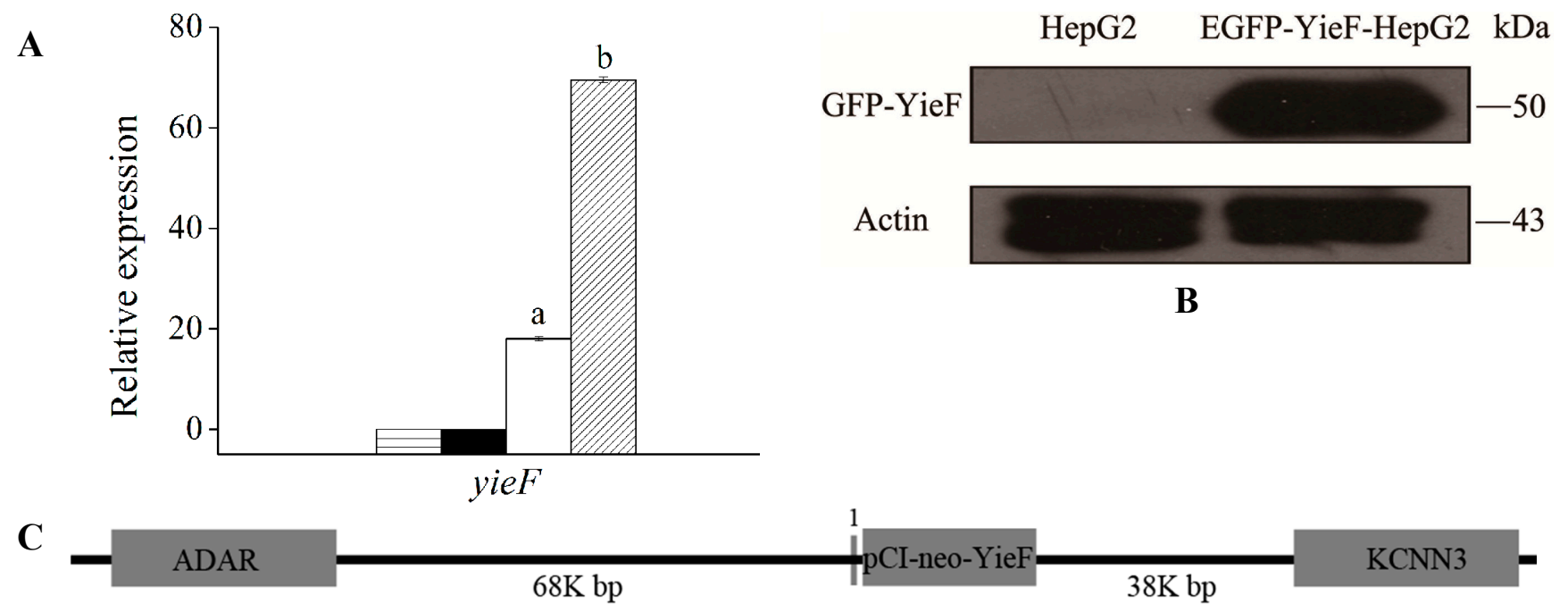

Figure 1. (A) The expression levels of gene yieF in different conditions determined by qRT-PCR. Relative level of yieF mRNA was measured in HepG2 (号), Cr(VI)-treated HepG2 (ロ), HepG2-YieF ( $\square$ ) and Cr(VI)-treated HepG2-YieF (沉) cells. Data were normalized to $\beta$-actin expression as a housekeeping gene. The values are the mean of four replicates. There are significant differences $(p<0.05)$ between the two bars marked a and b; (B) Detection of GFP-YieF fusion protein by western blotting. Molecular weight of GFP-YieF is about $50 \mathrm{kDa}$; (C) The integration of yieF in human chromosome 1 . Grey boxes on the $5^{\prime}$ and $3^{\prime}$ sides of yieF indicated genes located on Chr 1. Grey line immediately upstream of yieF marked 1 indicate predicted TF binding sites including TBP, Sp1 and CBP100 binding sites. The diagram was not drawn to scale. ADAR, adenosine deaminase, RNA-specific; KCNN3, potassium channel, calcium activated intermediate/small conductance subfamily $N \alpha$, member 3 .

The interesting finding of inducible expression of yieF could be explained by assuming that the genomic region into which yieF integrated was responsive to chromate stress. We therefore conducted genome walking to gain some information of the genomic sequence upstream of yieF intergration site. 
The sequencing result of genome walking indicated that yieF integrated between 156039118 and $156039119 \mathrm{bp}$ of the plus strand of human chromosome 1 (Figure 1C). The closest annotated gene on the $5^{\prime}$ side of yieF was over $60 \mathrm{~K}$ bp away, which was unlikely responsible for the inducible transcription of $y i e F$. Further prediction of transcription factor (TF) binding sites of the immediate upstream region of yieF integration site by TRANSFAC 4.0 revealed that -75 to -16 bp region contained binding sites for TBP (TATA box binding protein), Sp1 and CBP100 (CRE Binding Protein 100). As reported, Sp1 and $\mathrm{CBP}$ are redox-regulated, therefore herein the binding sites of these TFs might play a role during $\mathrm{Cr}(\mathrm{VI})$-induced oxidative stress to upregulate the expression of yieF [26]. Alternatively the chromate stress might elevate the levels of chaperones that could increase the level of functional YieF enzyme.

\subsection{Enhanced Cr(VI)-Reducing Ability of Cultured HepG2-YieF Cells and Crude Cell Extracts}

Both HepG2 cells and HepG2-YieF cells are capable of removing Cr(VI) from culture media within $36 \mathrm{~h}$ of culturing with $\mathrm{K}_{2} \mathrm{CrSO}_{4}$, but the reducing ability of the latter was significantly greater than the former (Figure 2A). In addition, to measure the in vitro reducing activities of reductants within HepG2-YieF cells, crude cell extracts were prepared from cultured cells. As shown in Figure 2B,C, the reduction rate of HepG2-YieF cell extract was consistently higher than that of HepG2. These results indicated that yieF increased the $\mathrm{Cr}(\mathrm{VI})$-reducing ability of HepG2 cells. We also compared the relative cell viabilities of HepG2-YieF and HepG2 and found that the viability of stable HepG2-YieF cells was significantly higher than that of HepG2 cells under Cr stress (Figure S2).

Although the recombinant YieF enzyme was somewhat effective in enhancing the reducing ability of HepG2, the overall effect and the time window of enzymatic activity appeared limited. Several reasons which deserved further analysis might contribute to the observed result. For example the recombinant enzyme might not be very stable and thus quickly degraded by proteasome. Or the expression might be low due to codon usage bias of mammalian cells. The yieF gene was subjected to the Codon Adaptation Index (CAI) measurement and scored 0.69, while a CAI greater than 0.8 was rated as good for expression in mammalian host (Available online: http://www.genscript.com/cgi-bin/tools/rare_codon_analysis). The rare codons in the reductase gene included TTA, GCG, GTA, and etc. A new yieF gene with optimized codons for mammalian systems could be synthesized and used for expressions in the future.
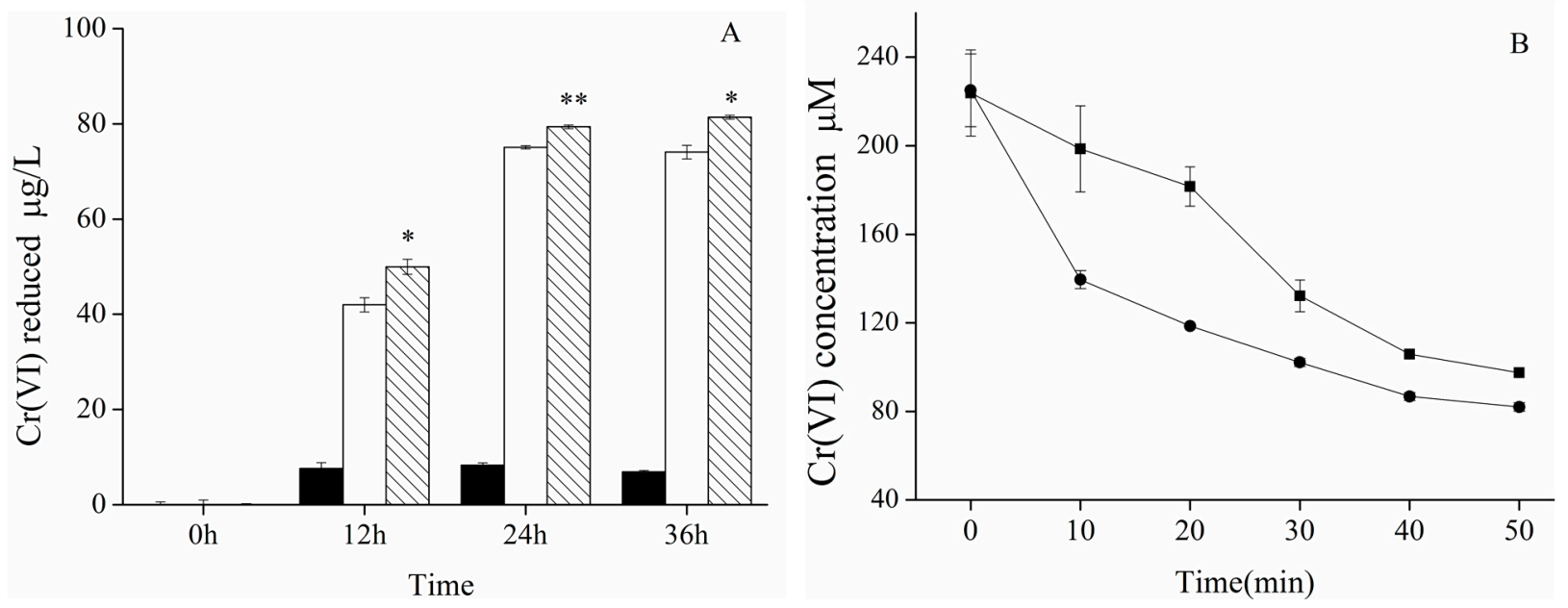

Figure 2. Cont. 


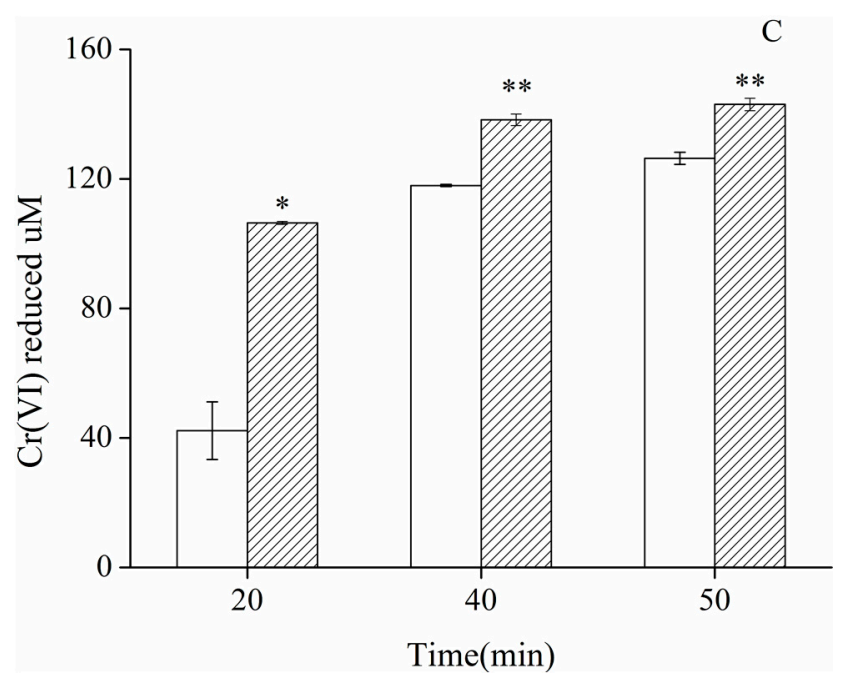

Figure 2. (A) Comparison of $\mathrm{Cr}(\mathrm{VI})$-reducing ability of cultured HepG2 ( $\square$ ) and HepG2-YieF $(\mathbb{\otimes})$ cells at different time points. ( $\mathbf{a})$ indicates cell-free control. $* p<0.05$, ** $p<0.01$; (B) Absolute concentration of remaining Cr(VI) in HepG2 ( $\mathbf{a})$ and HepG2-YieF $(\bullet)$ cell crude extract at different timepoints; (C) The lessened amount of Cr(VI) in HepG2 ( $\square$ ) and HepG2-YieF ( ${ }^{2}$ ) cell crude extract by calculation. Mean and SEs were obtained from three separate measurements of a representative experiment. Experiments were replicated at least twice. Error bars were in some cases smaller than the size of the symbol. * $p<0.05, * * p<0.01$.

\subsection{Expression Profiles of Glutathione Synthetase and Glutathione Reductase under Cr(VI) Treatment}

Some enzymes in mammalian cells are involved indirectly in the reduction of $\mathrm{Cr}$ (VI) to $\mathrm{Cr}$ (III), for example, glutathione synthetase (for GSH synthesis) and glutathione reductase (for the convertion of reduced GSH from its oxidized form) [27]. The expression of glutathione reductase gene was up-regulated in HepG2 control but down-regulated in HepG2-YieF cells under Cr(VI). Meanwhile, the expression of glutathione synthetase was downregulated in HepG2-YieF cells even without $\mathrm{Cr}(\mathrm{VI})$ treatment (Figure 3). These suggested that both of the two GSH-related enzymes were involved in $\mathrm{Cr}(\mathrm{VI})$ resistance in HepG2 cells and yieF expression might reduce the oxidative stress caused by $\mathrm{Cr}(\mathrm{VI})$.

\subsection{Localization of Recombinant EGFP-YieF Fusion Protein}

To visualize the localization of YieF, a fusion expression vector carrying YieF-EGFP was constructed and introduced to HepG2. $24 \mathrm{~h}$ after transfection, the expression of EGFP and EGFP-YieF was visualized by laser scanning confocal microscopy. The fluorescence was mainly localized in the nucleus of the cells that expressed EGFP only (Figure 4A-C), whereas the fluorescence in YieF-EGFP-transfected cells was detected in both nucleus and cytoplasm (Figure 4D-F), with slightly higher fluorescence intensity in the cytoplasm. This result demonstrated that fusion protein YieF-EGFP was localized in the cytoplasm where $\mathrm{Cr}$ reduction took place, possibly to protect the cell nucleus from $\mathrm{Cr}$ damage [28]. 


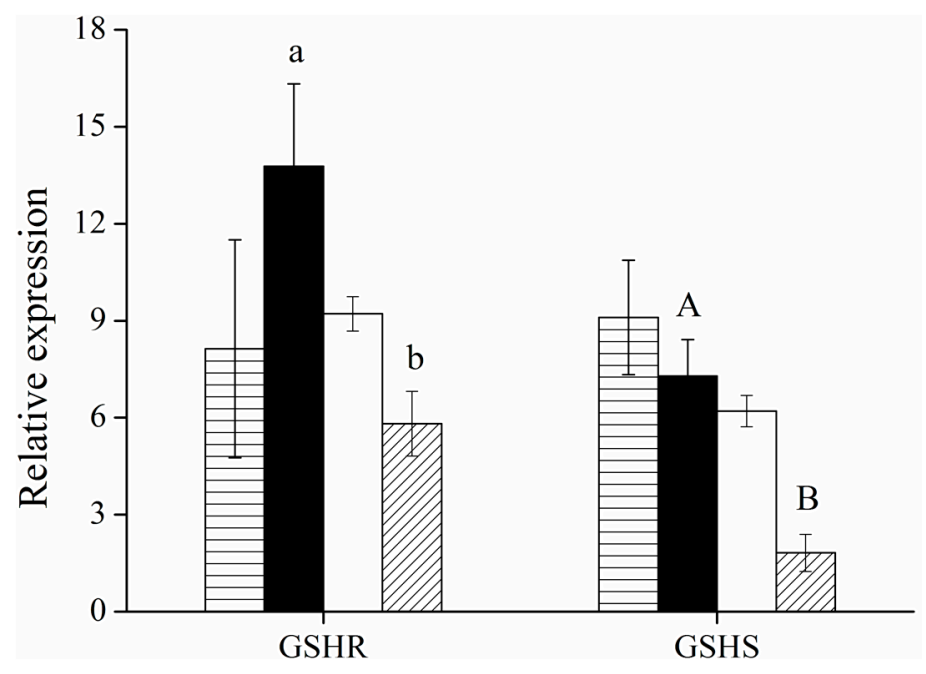

Figure 3. Relative mRNA expressions of glutathione reductase and glutathione synthetase were compared between transfectants and non-transfectants. Bars represent HepG2 without

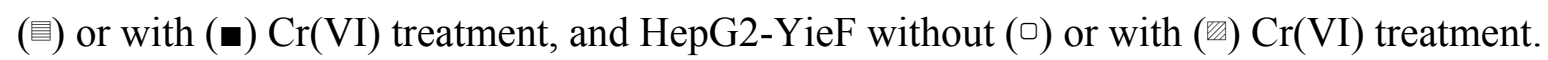
The values are the mean of four individual samples. Data were normalized to the expression of the housekeeping gene $\beta$-actin. Differences between bar a and $\mathrm{b}$ and between $\mathrm{A}$ and $\mathrm{B}$ are significant $(p<0.05)$.
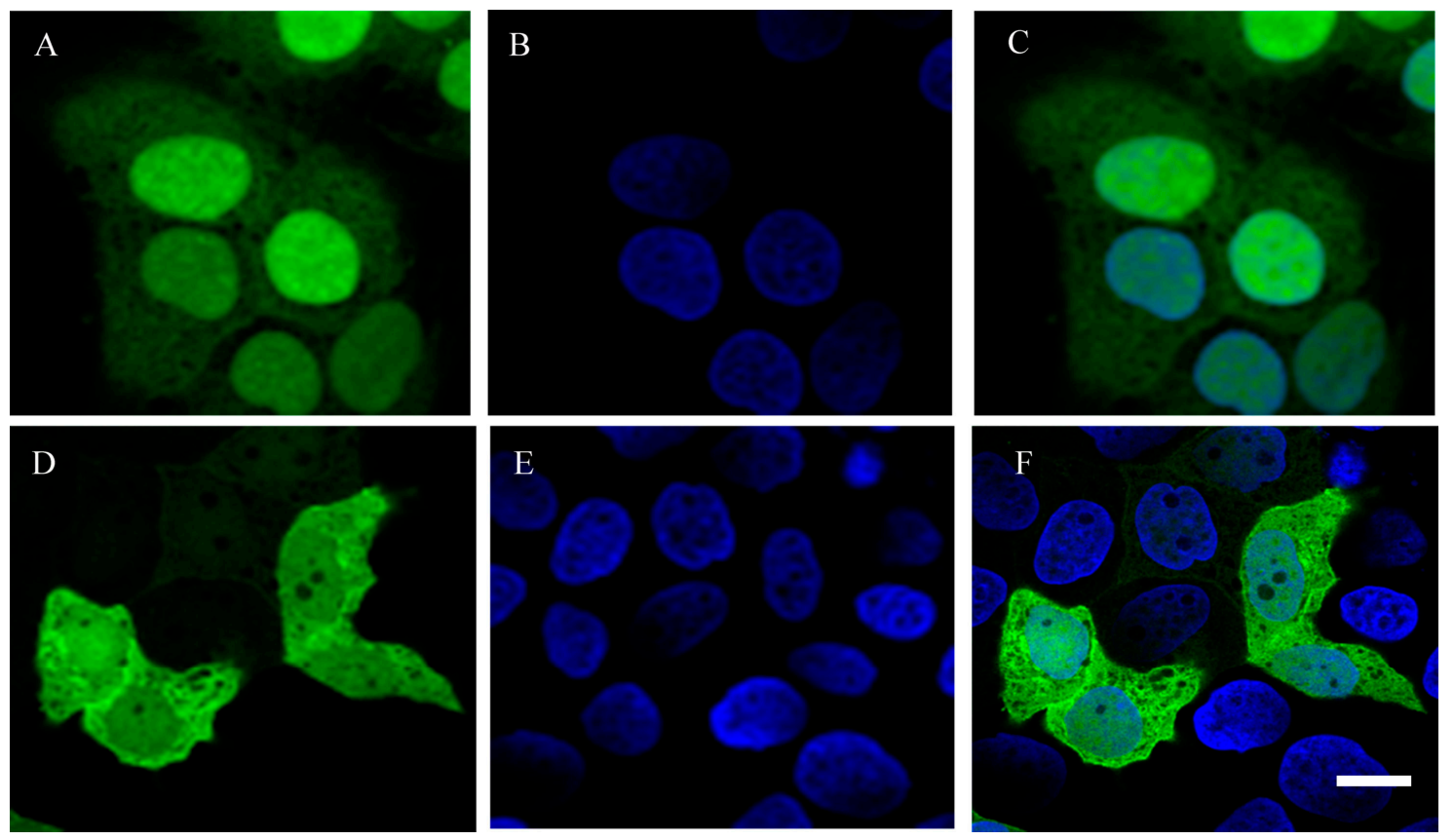

Figure 4. Localization of EGFP and YieF-EGFP fusion protein in transient transfectants. Green fluorescence indicated the localization of empty fluorescent vector EGFP (A) and fusion protein YieF-EGFP (D). Nuclei were counterstained with Hoechst 33258 (B,E). C is the overlay of $\mathbf{A}$ and $\mathbf{B}$, and $\mathbf{F}$ is the overlay of $\mathbf{D}$ and $\mathbf{E}$. Scale Bar $=10 \mu \mathrm{m}$. 


\section{Experimental Section}

\subsection{Plasmid Construction}

The coding region of yieF was amplified by PCR from genomic DNA of Escherichia coli. The primers used to construct pCI-neo-YieF and pEGFP-N1-YieF plasmid were listed in Table 1. PCR products were digested and inserted into mammalian expression vectors pCI-neo (Promega, Beijing, China) and fusion expression vector pEGFP-N1 (kindly provided by Zhang S.X. lab, Lanzhou, China). Pure Yield plasmid MidiPrep System (Promega, Beijing, China) was used to extract large quantities of plasmids according to the manufacturer's instructions.

Table 1. Primers used in this study.

\begin{tabular}{|c|c|}
\hline Primer & Sequences \\
\hline \multirow{2}{*}{ pCI-neo-YieF } & 5'-GAATTCTCTAGAATGTCTGAAAAATTGCAGGT-3'/ \\
\hline & 5'-GAATTCCCCGGGTCAGATCTTAACTCGCTGAATAA-3' \\
\hline \multirow{2}{*}{ pEGFP-N1-YieF } & 5'-GAATTCCTCGAGATGTCTGAAAAATTGCAGGT-3'/ \\
\hline & 5'-GAATTCCTGCAGGATCTTAACTCGCTGAATAAACT-3' \\
\hline \multirow{2}{*}{ yieF } & 5'-AGCTCATTTAATGGCATGG-3'/ \\
\hline & 5'-ATCAAGGGAATGTCGGCAA-3' \\
\hline \multirow{2}{*}{ glutathione synthetase } & 5'-TGGTCCAGTGCATTTCAGAG-3'/ \\
\hline & 5'-TTGGTTCGAAGTAGATGCCC-3' \\
\hline \multirow{2}{*}{ glutathione reductase } & 5'-TTACTGCAGTTCCCGGTAGG-3'/ \\
\hline & 5'-CTCAGGTCCTTGGTATTCGG-3' \\
\hline \multirow{2}{*}{$\beta$-actin } & 5'-ACATCCGCAAAGACCTGTATG-3'/ \\
\hline & 5'-GCCAG AG-CAGTGATCTCCTT-3' \\
\hline \multirow{3}{*}{$\mathrm{SP} *$} & 5'-TGACGGTTCACTAAACGAGCTCTGC-3'/ \\
\hline & 5'-ATCGCAGTTGTTACGACATTTTGGA-3'/ \\
\hline & 5'-ATCCCCGTGAGTCAAACCGCTATC-3' \\
\hline
\end{tabular}

* SP primers were used for Genome Walking to determine the nucleotide sequence upstream of yieF.

\subsection{Cell Culture, DNA Transfection and Cell Selection}

HepG2 cells were cultivated in Dulbecco's minimum essential medium DMEM (HyClone/high glucose) supplemented with 10\% fetal calf serum (Sijiqing, Beijing, China), $2 \mathrm{mM}$ L-glutamine, $100 \mathrm{U} / \mathrm{mL}$ penicillin, and $100 \mu \mathrm{g} / \mathrm{mL}$ streptomycin at $37{ }^{\circ} \mathrm{C}$ and $5 \% \mathrm{CO}_{2}$. Cells were inoculated into 96-well plate. After incubation for $24 \mathrm{~h}$, the cells were used for transfection. Into each well, $2 \mu \mathrm{L}$ pEGFP-YieF was added. pEGFP plasmid was used as the control. Transfection was performed using FuGENE ${ }^{\circledR} 6$ Transfection Reagent (Promega, Beijing, China) according to the manufacturer's instructions. Twenty-four hours after transfection, cells were harvested for analysis.

For stable transfection, cells were transfected as described above. Twenty-four hours after transfection, the standard culture medium was replaced by medium containing $800 \mu \mathrm{g} / \mathrm{mL}$ of selection reagent G418 (Geneticin, Invitrogen, Carlsbad, CA, USA) and cells were incubated in it for one week. After that, cells were maintained in $500 \mu \mathrm{g} / \mathrm{mL}$ G418 for two months for further screening. The survived cells were used as stably transfected cells for further analysis. 


\subsection{Western Blotting}

For protein extraction, cells were lysed with $100 \mu \mathrm{L}$ Ripa Lysis Buffer and centrifuged in 13,000 rpm for $10 \mathrm{~min}$. The concentration of protein was determined by bicinchoninic acid (BCA) protein assay. Protein extracts were electrophoretically resolved on 15\% SDS-PAGE and transferred onto a nitrocellulose membrane. Western blotting was carried out with standard protocol. Mouse monoclonal antibodies against GFP and $\beta$-actin were used as primary antibody (Roche, ZSGB-BIO, Beijing, China). Fluorescein-Conjugated AffiniPure Goat Anti-Mouse IgG was used as secondary antibody (ZSGB-BIO, China).

\subsection{Genome Walking}

HepG2 cells and HepG2-YieF cells were cultivated for $24 \mathrm{~h}$. DNA was extracted with TaKaRa MiniBEST Universal Genomic DNA Extraction Kit Ver.5.0 (TaKaRa, Dalian, China). Then the genomic sequence upstream of the yieF expression vector was obtained with Genome Walking Kit (TaKaRa, Dalian, China) according to the manufacturer's instruction. The PCR products were sequenced by Beijing Genomics Institute (Beijing, China). The primer used for Genome Walking were listed in Table 1.

\subsection{Chromate Reduction of Cell Culture and Crude Cell Extracts}

Cells were grown with $5 \mu \mathrm{M} \mathrm{Cr}(\mathrm{VI})$. One milliliter of culture medium was collected and briefly centrifuged after incubation with $\mathrm{Cr}(\mathrm{VI})$ for $0,12,24$ and $36 \mathrm{~h}$. The concentration of $\mathrm{Cr}(\mathrm{VI})$ in the culture medium was determined by DPC method. All experiments were performed with three replicates.

Crude cell extracts were obtained from HepG2 cells and HepG2-YieF cells. $2 \times 10^{7}$ cells were collected and disrupted by ultrasonication in ice water, and then centrifuged in $12,000 \times \mathrm{g}$ for five minutes. The supernatants were mixed with $200 \mu \mathrm{M} \mathrm{K}_{2} \mathrm{CrSO}_{4}$ solution and incubated in $37{ }^{\circ} \mathrm{C}$ water bath. One millilitre sample was taken out at 10, 20, 30, 40, and $50 \mathrm{~min}$ after incubation. $\operatorname{The} \operatorname{Cr}(\mathrm{VI})$ concentration of the samples were determined by DPC method [29]. All experiments were performed in three replicates.

\subsection{Expression Profiles of YieF, Glutathione Synthetase and Glutathione Reductase under Cr(VI) Treatment}

HepG2 cells and HepG2-YieF cells was cultivated with or without $5 \mu \mathrm{M} \mathrm{Cr}(\mathrm{VI})$ for $24 \mathrm{~h}$. Then cells were harvested and total RNA was extracted using RNAiso plus (Takara, Dalian, China) including a DNase digestion step. PrimeScript ${ }^{\circledR}$ RT reagent Kit (Takara, Dalian, China) was used for reverse transcription to generate cDNA.

Quantitative real-time PCR was carried out by SYBR Premix ExTapTM II (TaKaRa, Dalian, China) in a total volume of $10 \mu \mathrm{L}$ in Mx3005P QPCR Systems (Agilent, Santa Clara, CA, USA). The program of PCR was as followed: one cycle of $95{ }^{\circ} \mathrm{C}$ for $30 \mathrm{~s} ; 40$ cycles of $95{ }^{\circ} \mathrm{C}$ for $5 \mathrm{~s}, 58^{\circ} \mathrm{C}$ for $30 \mathrm{~s}$. For each PCR, a no-template reaction was included as negative control. Each cDNA sample was tested in duplicate. Gene $\beta$-actin was used as a reference gene. All primers were in Table 1. The following analysis was done with MxPro-Mx3005P software. 


\subsection{Laser Scanning Confocal Microscopy}

The transiently transfected cells were grown on coverslips and fixed with $4 \%$ paraformaldehyde solution for thirty minutes at room temperature. After fixation, cells were washed and stained with Hoechst 33258 (Sigma, St. Louis, MO, USA). Coverslips were mounted on slides with glycerinum. Images were taken with 100-fold oil objective on Olympus FV1000 fluorescence microscope (Olympus, Tokyo, Japan), and processed using Olympus Fluoview ver.2.1c viewer Software.

\section{Conclusions}

Bacterial chromate-reducing gene yieF was successfully transfected and expressed in human HepG2 cells. The tolerence to $\mathrm{Cr}(\mathrm{VI})$ and the reduction ability of HepG2 were enhanced. Therefore, transgenic expression of bacterial chromate reductase is potentially useful to increase the resistance to chromate in mammals.

\section{Supplementary Materials}

Supplementary materials can be found at http://www.mdpi.com/1422-0067/16/06/11892/s1.

\section{Acknowledgments}

This work was supported by a National Natural Science Foundation grant 31100888 to Pu Liu.

\section{Author Contributions}

Xuan Liu conducted most of the experiment. Gaofeng Wu prepared the manuscript. Yanli Zhang and Dan Wu provided assistance in cell culture. Xiangkai Li gave advice in experimental design. Pu Liu designed the experiments.

\section{Conflicts of Interest}

The authors declare no conflict of interest.

\section{References}

1. Bryant, H.E.; Ying, S.; Helleday, T. Homologous recombination is involved in repair of chromium-induced DNA damage in mammalian cells. Mutat. Res. 2006, 599, 116-123.

2. Wuana, R.A.; Okieimen, F.E. Heavy metals in contaminated soils: A review of sources, chemistry, risks and best available strategies for remediation. ISRN Ecol. 2011, 2011, doi:10.5402/2011/402647.

3. Di Bona, K.R.; Love, S.; Rhodes, N.R.; McAdory, D.; Sinha, S.H.; Kern, N.; Kent, J.; Strickland, J.; Wilson, A.; Beaird, J.; et al. Chromium is not an essential trace element for mammals: Effects of a "low-chromium" diet. J. Biol. Inorg. Chem. 2011, 16, 381-390.

4. Kimbrough, D.E.; Cohen, Y.; Winer, A.M.; Creelman, L.; Mabuni, C. A critical assessment of chromium in the environment. Crit. Rev. Environ. Sci. Technol. 1999, 29, 1-46. 
5. Costa, M.; Klein, C.B. Toxicity and carcinogenicity of chromium compounds in humans. CRC Crit. Rev. Toxicol. 2006, 6, 155-163.

6. Leonard, A.; Lauwerys, R. Carcinogenicity and mutagenicity of chromium. Mutat. Res. 1980, 76, 227-239.

7. Megharaj, M.; Avudainayagam, S.; Naidu, R. Toxicity of hexavalent chromium and its reduction by bacteria isolated from soil contaminated with tannery waste. Curr. Microbiol. 2003, 47, 51-54.

8. Straif, K.; Benbrahim-Tallaa, L.; Baan, R.; Grosse, Y.; Secretan, B.; El Ghissassi, F.; Bouvard, V.; Guha, N.; Freeman, C.; Galichet, L. A review of human carcinogens-Part C: Metals, arsenic, dusts, and fibres. Lancet Oncol. 2009, 10, 453-454.

9. Huamain, C.; Chunrong, Z.; Cong, T.; Yongguan, Z. Heavy metal pollution in soils in China: Status and countermeasures. Ambio 1999, 28, 130-134.

10. Nriagu, J.O.; Nieboer, E. Chromium in the Natural and Human Environments; John Wiley \& Sons: Hoboken, NJ, USA, 1988.

11. Loza-Tavera, H.; Torres-Guzmän, J.C.; Moreno-Sänchez, R. Interactions of chromium with microorganisms and plants. FEMS Microbiol. Rev. 2001, 25, doi: 10.1111/j.1574-6976.2001. tb00581.x.

12. Itoh, M.; Nakamura, M.; Suzuki, T.; Kawai, K.; Horitsu, H.; Takamizawa, K. Mechanism of chromium (VI) toxicity in Escherichia coli: Is hydrogen peroxide essential in $\mathrm{Cr}$ (VI) toxicity. J. Biochem. 1995, 117, 780-786.

13. Bagchi, D.; Bagchi, M.; Stohs, S.J. Chromium(VI)-induced oxidative stress, apoptotic cell death and modulation of p53 tumor suppressor gene. In Molecular Mechanisms of Metal Toxicity and Carcinogenesis; Springer: New York City, NY, USA, 2001; pp. 149-158.

14. Mikalsen, A.; Alexander, J.; Wallin, H.; Ingelman-Sundsberg, M.; Anderson, R. Reductive metabolism and protein binding of chromium(VI) by P450 protein enzymes. Carcinogenesis 1991, $12,825-831$.

15. Levis, A.; Majone, F. Cytotoxic and clastogenic effects of soluble chromium compounds on mammalian cell cultures. Br. J. Cancer 1979, 40, 523-533.

16. Tebo, B.M.; Obraztsova, A.Y. Sulfate-reducing bacterium grows with Cr(VI), U(VI), Mn(IV), and Fe(III) as electron acceptors. FEMS Microbiol. Lett. 1998, 162, 193-198.

17. Shen, H.; Wang, Y. Characterization of enzymatic reduction of hexavalent chromium by Escherichia coli ATCC 33456. Appl. Environ. Microbiol. 1993, 59, 3771-3777.

18. Zheng, Z.; Li, Y.; Zhang, X.; Liu, P.; Ren, J.; Wu, G.; Zhang, Y.; Chen, Y.; Li, X. A Bacillus subtilis strain can reduce hexavalent chromium to trivalent and an $\mathrm{nfrA}$ gene is involved. Int. Biodeterior. Biodegrad. 2015, 97, 90-96.

19. Barak, Y.; Thorne, S.H.; Ackerley, D.F.; Lynch, S.V.; Contag, C.H.; Matin, A. New enzyme for reductive cancer chemotherapy, YieF, and its improvement by directed evolution. Mol. Cancer Ther. 2006, 5, 97-103.

20. Ackerley, D.; Gonzalez, C.; Keyhan, M.; Blake, R.; Matin, A. Mechanism of chromate reduction by the Escherichia coli protein, NfsA, and the role of different chromate reductases in minimizing oxidative stress during chromate reduction. Environ. Microbiol. 2004, 6, 851-860.

21. Alvarez, A.H.; Moreno-Sánchez, R.; Cervantes, C. Chromate efflux by means of the ChrA chromate resistance protein from Pseudomonas aeruginosa. J. Bacteriol. 1999, 181, 7398-7400. 
22. Moch, C.; Schrogel, O.; Allmansberger, R. Transcription of the nfrA-ywcH operon from Bacillus subtilis is specifically induced in response to heat. J. Bacteriol. 2000, 182, 4384-4393.

23. Zhitkovich, A. Importance of chromium-DNA adducts in mutagenicity and toxicity of chromium(VI). Chem. Res. Toxicol. 2005, 18, 3-11.

24. Dayan, A.; Paine, A. Mechanisms of chromium toxicity, carcinogenicity and allergenicity: Review of the literature from 1985 to 2000. Hum. Exp. Toxicol. 2001, 20, 439-451.

25. Jin, T.-E.; Kim, I.-G.; Kim, W.-S.; Suh, S.-C.; Kim, B.-D.; Rhim, S.-L. Expression of chromium(VI) reductase gene of heavy metal reducing bacteria in tobacco plants. J. Plant Biotechnol. 2001, 3, 13-17.

26. Hawkes, H.J.; Karlenius, T.C.; Tonissen, K.F. Regulation of the human thioredoxin gene promoter and its key substrates: A study of functional and putative regulatory elements. Biochim. Biophys. Acta 2014, 1840, 303-314.

27. Zhitkovich, A.; Voitkun, V.; Costa, M. Glutathione and free amino acids form stable complexes with DNA following exposure of intact mammalian cells to chromate. Carcinogenesis 1995, 16, 907-913.

28. Wang, X.-F.; Xing, M.-L.; Shen, Y.; Zhu, X.; Xu, L.-H. Oral administration of Cr(VI) induced oxidative stress, DNA damage and apoptotic cell death in mice. Toxicology 2006, 228, 16-23.

29. Pettine, M.; Capri, S. Digestion treatments and risks of $\mathrm{Cr}(\mathrm{III})-\mathrm{Cr}(\mathrm{VI})$ interconversions during $\mathrm{Cr}(\mathrm{VI})$ determination in soils and sediments-A review. Anal. Chim. Acta 2005, 540, 231-238.

(C) 2015 by the authors; licensee MDPI, Basel, Switzerland. This article is an open access article distributed under the terms and conditions of the Creative Commons Attribution license (http://creativecommons.org/licenses/by/4.0/). 